\title{
Effects of HMB Supplementation on Body Composition of Rats
}

\author{
Efectos de la Suplementación con HMB sobre la Composición Corporal en Ratas
}

\begin{abstract}
Rafael Gavassa de Araujo ${ }^{1}$; Robson Chacon Castoldi²; Carolina Cabral Dos Santos ${ }^{3}$; Joao Henrique Lyrio Machado ${ }^{3}$; Guilherm Akio Tamura Ozaki ${ }^{3}$; Thiago Alves Garcia ${ }^{3}$; Giovana Rampazzo Teixerira ${ }^{3}$; Jose Carlos Silva Camargo Fihlo ${ }^{3} \&$ Marcelo Papoti $^{4}$
\end{abstract}

ARAUJO, R. G.; CASTOLDI, R. C.; DOS SANTOS, C. C.; MACHADO, J. H. L.; OZAKI, G. A. T.; GARCIA, T. A.; TEIXERIRA, G. R.; FIHLO, J. C. S. C. \& PAPOTI, M. Effects of HMB supplementation on body composition of rats. Int. J. Morphol., 35(2):705$710,2017$.

SUMMARY: The aim was to investigate the effects of HMB supplementation on the physical performance and anthropometric parameters of Wistar rats that underwent eight weeks of concurrent training. We used 22 male Wistar rats of approximately 60 days of age, And were divided into four groups: control (C), supplemented control (SC), exercise (E) and supplemented exercise (SE). The training consisted of 30 minutes of swimming with an overload corresponding to $70 \%$ of the anaerobic threshold, a one-minute interval, and four sets of ten jumps in water with a one minute interval between sets and a load of $50 \%$ of body weight. After the tests, the tLIM and TTESTE were obtained and used to evaluate the performance of the animals, and anthropometric indices evaluated. The weight increases during the treatment in the SC animals was significantly higher than the animals in groups $\mathrm{C}$ and $\mathrm{E}$. The absolute weight of the muscles, kidney and epididymal fat showed higher values for the SC and SE groups in relation to the others.

KEY WORDS: Concurrent training, Performance, Anthropometic measures, Wistar Rats.

\section{INTRODUCTION}

Physical training leads to different biological adaptations aimed at improving performance in a specific activity. To obtain significant changes in performance, knowledge of the physiological, metabolic and functional effects of exercises and combinations thereof is essential.

There is still controversy in the literature with regard to the effectiveness of concurrent training (CT). The difficulty entailed in establishing a precise relation in CT is due to the extensive range of training protocols studied, as well as the various changes that have been underreported in the literature to date. The difference in results appears to be related to the protocol used, which includes the volume, duration, frequency, intensity, population, initial level of fitness and statistical analysis used (Paulo et al., 2005; Guedes Junior, 2003).

CT refers to a program that combines strength training (ST) and endurance training (ET) in the same period, as well as possible changes resulting from these two antagonistic abilities (Mccarthy et al., 2002). The reason for performing concurrent training is that the benefits of strength training and endurance will be acquired simultaneously (Leveritt $e t$ al., 2003).

Associated with training, nutrition is an important aspect within sports practice, because, when well directed, it helps reduce fatigue by allowing the athlete better recovery and yield (França et al., 2006). Many athletes seek ways to improve the physical performance provided by training and, for this, often turn to food supplements as a nutritional strategy.

ß-hydroxy ß-methylbutyrate (HMB) has been considered as an augmentation agent to elevate strength levels, enhance gains in size and prevent muscle tissue breakdown when combined with physical training. In addition, it has been shown to reduce tumor mass by reducing the protein involved in cell proliferation, resulting in a decrease in total cholesterol, LDL and diastolic (Nunes et al., 2008; Nissen et al., 2000).

\footnotetext{
${ }^{1}$ Universidade Estadual de Campinas - UNICAMP, Brasil.

${ }^{2}$ Universidade do Oeste Paulista - UNOESTE. Brasil.

${ }^{3}$ Universidade Estadual Paulista "Júlio de Mesquita Filho" - UNESP. Brasil.

${ }^{4}$ Universidade São Paulo, USP, Brazil.
} 
HMB is a by-product of the leucine metabolism and is synthesized from acetoisocaproato (KIC) in the liver, cytosol of hepatocytes, and muscle cells. First, it is converted into beta-hydroxy-ß-methylglutaryl coenzyme A (HMG-CoA) and can follow two distinct metabolic pathways: one through the action of the enzyme HMGCoA reductase, which is a limiting factor for the synthesis of cholesterol, when there is a great demand for the formation of cell membranes (as occurs during periods of muscle cell growth and repair), which converts HMG-CoA into cholesterol. The second by the enzyme HMG-CoA synthetase which converts HMG-CoA into acetyl-CoA, a substrate for the generation of energy (Alvares \& Meirelles, 2008).

Thus, according to Nissen et al. supplementation would aid the ability to reduce the damage that physical exercise can cause in the body, causing an anti-catabolic effect, suppressing protein breakdown and preserving the accumulation of amino acids in the muscles, exerting influence on strength and muscle mass.

In this sense, the aim of this study was to investigate the effects of HMB supplementation on the physical performance and anthropometric parameters of Wistar rats that underwent eight weeks of concurrent training.

\section{MATERIAL AND METHOD}

Animals. We used 22 male Wistar rats, of approximately 60 days of age, obtained from the Central Animal Facility of UNESP, Botucatu/SP. The animals remained in collective cages lined with wood shavings, at a controlled room temperature $\left(22 \pm 2{ }^{\circ} \mathrm{C}\right)$ and light/dark cycle of $12 \mathrm{~h}$ in the animal house of UNESP, Presidente Prudente/SP. They had access to food (Labina-PURINA ${ }^{\circledR}$ ) and water ad libitum, following the Standards and Ethical Principles of Animal Experimentation, after prior approval by the Ethics Committee for Animal Research of the FCT / UNESP - Presidente Prudente/SP, Protocol 03/2011.

Adaptation to the Liquid Environment. In order to reduce stress before the physical exercise and to familiarize the animals with the equipment, they underwent a three week adaption to the liquid environment in individual PVC cylindrical tanks $(120 \times 60 \mathrm{~cm})$ with a controlled temperature $\left(31 \pm 1{ }^{\circ} \mathrm{C}\right)$ and sessions of 30 minutes, held three times weekly.

Design of Groups. After the adaptation period, the animals were randomly divided into four groups, namely:
- Control (C): the animals remained in their cages with food and water ad libitum and received no physical stimulation $(\mathrm{n}=7)$;

- Supplemented Control (SC): the animals remained in their cages with food and water ad libitum, they did not receive any physical stimulation and were supplemented daily with $\operatorname{HMB}(\mathrm{n}=5)$;

- Exercised (E): the animals underwent the CT protocol $(\mathrm{n}=5)$;

- Supplemented exercised (SE): the animals underwent the CT protocol and were supplemented daily with HMB $(\mathrm{n}=5)$.

HMB Supplementation. The commencement of oral administration of HMB (ARNOLD NUTRITION INC., HOLLYWOOD, FL) coincided with the start of training. It was administered by gavage to the $\mathrm{SC}$ and $\mathrm{SE}$ groups (30 minutes before the training protocol), in a single dosage consisting of $76 \mathrm{mg} / \mathrm{kg} / \mathrm{day}$, this being equivalent to the dose used in studies involving humans with HMB supplementation (Gallagher et al., 2000), which corresponds to approximately 3-6 g/day of HMB for a person weighing $80 \mathrm{~kg}$.

Concurrent Training Protocol. The exercise sessions were performed in sequence, with a one minute interval between the ET and the ST, three days a week (Spagnol et al., 2012).

Endurance training (ET): composed of a swimming session lasting 30 minutes held in PVC cylindrical tanks, with each animal individually trained. We used a constant overload, referring to a percentage of the body weight (BW) of each animal which had been previously established in a lactate minimum test corresponding to 70 $\%$ of anaerobic threshold (AT).

Strength Training (ST): consisted of four sets of 10 jumps in a cylindrical PVC tank, specially modified for jumping in the water $(90 \times 60 \mathrm{~cm})$. Between each series was an interval of one minute. The overload was constant and relative to $50 \%$ of the BW of each animal. The overload was accommodated in the anterior chest region by means of a vest specifically designed for this type of jump (De Mello Malheiro et al., 2009).

Figure 1 demonstrates how the experiment was conducted, from the division of the groups, completion of LMT and procedures each group was submitted to after the test. 


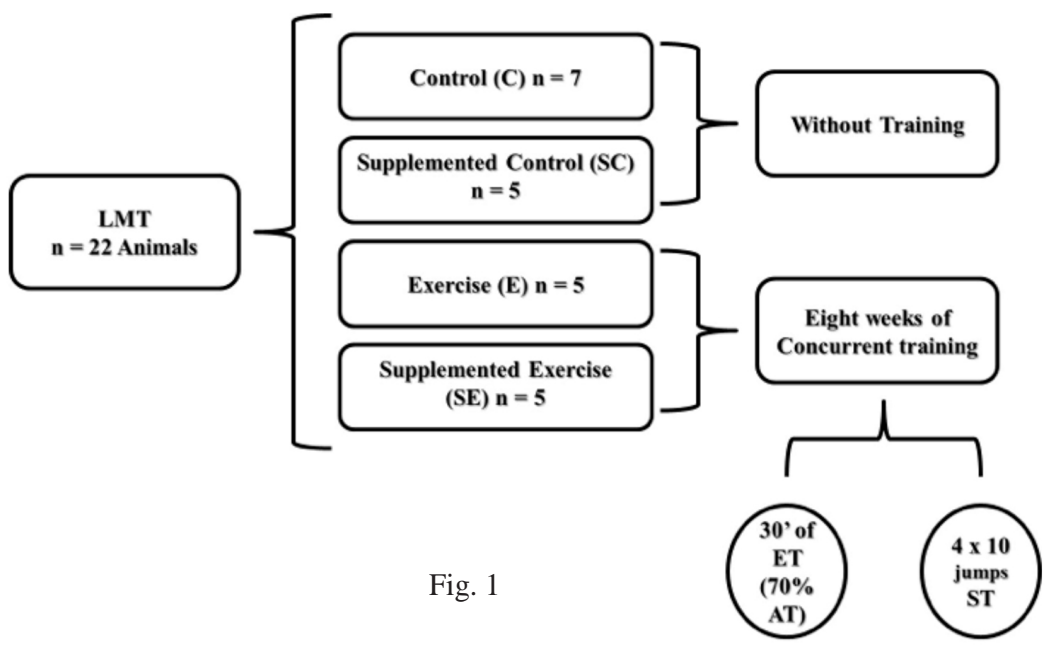

Determination of Aerobic and Anaerobic Performances and Prescription of Endurance Training. The aerobic and anaerobic performances were considered as the intensity of AT and timeout of the lactate minimum test (tLIM). To determine these variables, we used the lactate minimum test (LM) validated in humans by, applied to rats by and improved for these animals by (Tegtbur et al., 1993; Voltarelli et al., 2002; de Araujo et al., 2007).

The performance evaluation procedure was used as a method for anaerobic hyperlactacidemia induction with a load corresponding to $13 \%$ of BW for each animal. The animals performed two efforts in this first phase of the trial, the first lasting 30 seconds and, after an interval of 30 s, the second effort, with the same load, until exhaustion (tLIM). Blood samples $(25 \mathrm{~mL})$ were collected from the distal end of the tail 1, 3, 5, 7 and 9 minutes after the tLIM to determine the lactate peak concentration.

After nine minutes of passive recovery, the rats underwent an incremental test to determine the intensity of AT, in which the same overload percentages as for the endurance training were used. The loads were equivalent to 4.0, 4.5, 5.0, 5.5, 6.0 and $7.0 \%$ of the BW of each animal, each stage lasting for five minutes with a 30 s interval for the purposes of collecting blood samples. After electrochemical analysis in a lactate analyzer (YSI Model Sport Spring - 1500), the ratio between lactate concentration and load (percentage of body weight) was adjusted by a polynomial equation of order 2 , and the AT was considered the zero derivative of this adjustment.

Anthropometric Analysis. At the end of eight weeks of the experiment, the following measurements were taken:
- Total body weight using an electronic scale (Shimadzu ${ }^{\circledR}$ $\mathrm{BL} 3200 \mathrm{H}$, accurate to $0.01 \mathrm{~g}$ )

- Percentage of Weight Gain for calculating the change in body weight (\%) (Equation 1)

- Nasal-anal length (NAL)

- Lee index (LI) for rats, which is the equivalent to BMI in humans, and takes into account the distribution of mass (g) by body surface area $(\mathrm{cm})$ (Equation 2$)$.

$$
\mathrm{Eq} 1 . \mathrm{D}=[(\mathrm{BWF}-\mathrm{BWI}) / \mathrm{BWI}] * 100
$$

Where: BWF is the final body weight; BWI is the initial body weight.

$$
\mathrm{Eq} 2 . \mathrm{LI}=[(3 \sqrt{\mathrm{BW}}) / \mathrm{NAL}] * 10
$$

Where: NAL is the nasal-anal length; BW is the body weight.

After the measurements, the animals were euthanized using an overdose of sodium pentobarbital (100 $\mathrm{mg} / \mathrm{kg}$ ) applied intraperitoneally 48 hours after the last training session. The removal of the ventral portion of the biceps, gastrocnemius, plantaris, soleus and triceps muscles, as well as the liver, kidney and epididymal fat was standardized.

Statistical Analyses. To test the normality of data the Komolgorov-Smirnov test was used, verifying that the data were normally distributed we used one-way ANOVA for comparison of means between groups, with the post hoc Tukey. Statistical analysis was performed using STATISTICA $7^{\circledR}$ (STATSOFT). For all analyzes the significance level was set at $5 \%$. The results were expressed as mean \pm standard deviation. 


\section{RESULTS}

Progressive weight gain was monitored throughout the treatment period. There were no significant differences in the body mass of animals in any group until the fourth week (Fig. 2). However, it was possible to observe statistically significant differences in the total body mass of the animals between the fourth and eighth weeks. The SC group showed higher mass gain during the treatment compared to the other groups (Fig. 2).

Table I shows the average weight of the muscles after 8 weeks of treatment, analyzed in the four experimental groups, where significant differences were observed in the weight of the gastrocnemius, soleus, biceps and triceps between the SC and C group.

It was observed that both the weight of the liver, renal and epidydimal fat used as indirect markers in body composition were significantly lower in the SE and E groups than the $\mathrm{C}$ and SC groups (Table II).
Values of tLIM obtained before and after eight weeks of training. It was observed that there were no differences between the two evaluations in any of the four groups of animals (Table III).

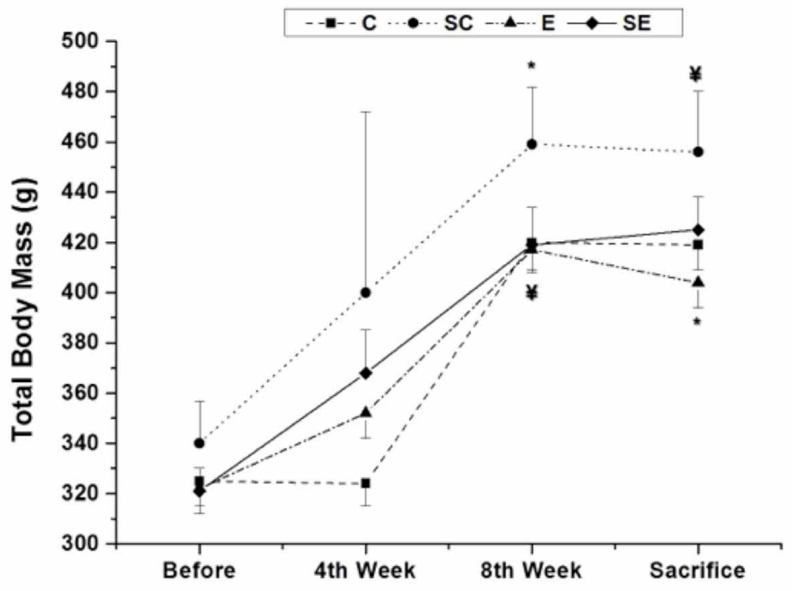

Table I. Average weight of the muscles analyzed in the four experimental groups.

\begin{tabular}{lllll}
\hline Variables & C & SC & E & SE \\
\hline \multicolumn{1}{c}{ ABSOLUTE } & & & & \\
\hline Plantar is (g) & $0.39 \pm 0.06$ & $0.40 \pm 0.05$ & $0.39 \pm 0.02$ & $0.40 \pm 0.04$ \\
Gastrocnemius (g) & $1.94 \pm 0.17$ & $2.09 \pm 0.21$ & $2.05 \pm 0.07$ & $2.05 \pm 0.17$ \\
Soleus (g) & $0.21 \pm 0.03$ & $0.23 \pm 0.04$ & $0.21 \pm 0.02$ & $0.20 \pm 0.02$ \\
Bic eps (g) & $1.59 \pm 0.24$ & $1.87 \pm 0.26$ & $1.86 \pm 0.12$ & $1.84 \pm 0.10$ \\
Triceps (g) & $0.30 \pm 0.12$ & $0.53 \pm 0.03^{*}$ & $0.45 \pm 0.06^{*}$ & $0.49 \pm 0.06^{*}$ \\
\hline \multicolumn{1}{c}{ RELATIVE } & & & & \\
\hline Plantaris (g) & $0.09 \pm 0.01$ & $0.09 \pm 0.01$ & $0.10 \pm 0.00$ & $0.09 \pm 0.00$ \\
Gastrocnemius (g) & $0.45 \pm 0.02 ¥$ & $0.47 \pm 0.03 ¥$ & $0.51 \pm 0.02$ & $0.48 \pm 0.01$ \\
Soleus (g) & $0.05 \pm 0.00$ & $0.05 \pm 0.00$ & $0.05 \pm 0.00$ & $0.05 \pm 0.00$ \\
Biceps (g) & $0.37 \pm 0.05$ & $0.42 \pm 0.05$ & $0.46 \pm 0.02^{*}$ & $0.43 \pm 0.02^{*}$ \\
Triceps (g) & $0.07 \pm 0.02$ & $0.12 \pm 0.01^{*}$ & $0.11 \pm 0.01^{*}$ & $0.12 \pm 0.01^{*}$ \\
\hline
\end{tabular}

* Significant differences in the $\mathrm{C}$ group; $¥$ Significant differences in the $\mathrm{E}$ group; $\mathrm{p}<0.05$.

Table II. Mean values of liver weight and body composition indices in the four experimental groups.

\begin{tabular}{lllll}
\hline Variables & $\mathrm{C}$ & $\mathrm{SC}$ & $\mathrm{E}$ & $\mathrm{SE}$ \\
\hline & & ABSOLUTE & & \\
\hline Liver $(\mathrm{g})$ & $15.89 \pm 3.48$ & $16.94 \pm 3.55$ & $12.89 \pm 3.70$ & $15.95 \pm 2.14$ \\
Epidydimal fat $(\mathrm{g})$ & $4.84 \pm 1.23$ & $5.18 \pm 1.25$ & $3.69 \pm 0.51$ & $3.40 \pm 0.46^{*}$ \\
Renal fat $(\mathrm{g})$ & $4.54 \pm 1.48 ¥$ & $5.09 \pm 2.21 ¥$ & $2.16 \pm 0.53$ & $2.90 \pm 0.49$ \\
Lee Index (g) & $2.96 \pm 0.06^{*}$ & $3.08 \pm 0.06$ & $2.99 \pm 0.06$ & $3.06 \pm 0.08$ \\
\hline & & RELATIVE & \\
\hline Liver (g) & $3.70 \pm 0.74$ & $3.76 \pm 0.32$ & $3.18 \pm 0.35$ & $3.73 \pm 0.42$ \\
Epidydimal fat $(\mathrm{g})$ & $1.12 \pm 0.25 £$ & $1.15 \pm 0.18 £$ & $0.91 \pm 0.09$ & $0.81 \pm 0.14$ \\
Renal fat $(\mathrm{g})$ & $1.06 \pm 0.34 ¥$ & $1.12 \pm 0.45 ¥$ & $0.53 \pm 0.12$ & $0.69 \pm 0.15$ \\
\hline
\end{tabular}

* Significant differences in the SC group; $¥$ Significant differences in the E group; $¥$ Significant differences in the SE group; $p<0.05$.

Table III. tLIM average values before and after eight weeks of concurrent training.

\begin{tabular}{lllll}
\hline Variables & $\mathbf{C}$ & $\mathbf{S C}$ & $\mathbf{E}$ & $\mathbf{S E}$ \\
\hline $\mathbf{t}_{\text {LIM BEFORE }}(\mathbf{s})$ & $63.86 \pm 14.60$ & $64.80 \pm 9.42$ & $69.80 \pm 25.53$ & $62.80 \pm 13.22$ \\
$\mathbf{t}_{\text {LIM AFTER }}(\mathbf{s})$ & $50.29 \pm 3.86$ & $49.00 \pm 9.43$ & $54.00 \pm 8.80$ & $54.20 \pm 15.22$ \\
\hline
\end{tabular}




\section{DISCUSSION}

The purpose of this study was to verify the effect of HMB supplementation on the body composition and physical performance of Wistar rats that underwent eight weeks of concurrent training. HMB has been used for healthy individuals aiming to increase free-fat mass, however, the results are controversial.

There was a significant reduction in the total $\mathrm{BW}$ in the animals of the exercised group compared to the control group. This reduction can be explained by CT, since, according to Carvalho et al. (2009), exercise requires the animals to perform activities at higher intensities, providing greater energy demands and the recruitment of different muscle groups thus inducing several biochemical adaptations in different organic levels (such as muscle tissues and liver) by facilitating the mobilization and oxidation of triacylglycerol and exerting a conservative effect on lean body tissue (McArdle et al., 2003).

However, the opposite was found between the HMB supplemented groups with the SE group presenting a greater weight gain than that found in the E Group (a $21 \%$ difference in the acquisition of body weight). A contrary result to that found in this study was described by Nissen et al., with a supplement of $3 \mathrm{~g}$ of $\mathrm{HMB} /$ day for three weeks in subjects that underwent three sessions of ST per week, lasting 90 minutes, during which the supplement was able to increase strength and lean mass measured by bioelectrical impedance.

In their studies reported an increased activity of creatine kinase $(\mathrm{CK})$ and reduction in plasma lactate dehydrogenase (LDH) in an HMB-supplemented group, as well as the decrease in urinary excretion of 3-methyl-histidine during training, which indicates lower rates of proteolysis, thus consolidating the hypothesis that supplementation helps prevent exerciseinduced muscle damage (Knitter et al., 2000). In this sense, an increase in muscle weight was found when comparing the $\mathrm{E}$ and $\mathrm{C}$ groups. This noticeable difference in the muscles involved in the exercise performed, suggests that the increased protein intake from the supplements was necessary for the manifestation of better adaptive responses of the skeletal muscle working during the $\mathrm{CT}$.

It is known that the increase in muscle mass is due to the increase in the number and diameter of myofibrils resulting in an increase in the cross-sectional area (CSA). This response is a consequence of the accumulation of contractile proteins in muscle fibers, when the rate of protein synthesis is greater than the degradation (Bodine, 2006; Souza, 2010).

We also evaluated the Lee index (LI) in rats. The World
Health Organization (WHO, 1998) classifies people with a BMI of less than $18.5 \mathrm{~kg} / \mathrm{m}^{2}$ as underweight, between 18.5 and 24.9 $\mathrm{kg} / \mathrm{m}^{2}$ as ideal weight, between 25 and $29.9 \mathrm{~kg} / \mathrm{m}^{2}$ as overweight and above $30 \mathrm{~kg} / \mathrm{m}^{2}$ as obese.

According to this classification, from values obtained using the Lee index, the supplemented animals fall into obese grade 1, while the non-supplemented groups are excess weight. However, this factor alone can lead to misinterpretation, because it takes into account factors such as lean mass, bone mass, age, and sex of the individual biotype (Lochaidy et al., 2012). The classification can only rank a person within a healthy range of generalized values. In their studies show that obesity is a public health problem, and that this matter should be investigated (de Lima et al.). With the use of rats, one can better visualize the actual effect of training on anthropometric indices, which are directly linked to obesity. This study observed a reduction in renal fat, demonstrating the effectiveness of CT in improving body composition.

This study evaluated the tLIM in the pre and post training. There were no differences in the values for the tLIM. Given that both groups showed similar responses (reduction), with less of a decline in the supplemented group. A similar result was described by Pereira et al. (2002), in which training effects were observed at intensities of 85,90 and $100 \%$ of AT. It was reported that training was not able to stimulate gains in aerobic capacity.

In another study, the high volume of training loads provided a steady increase in CK values in groups at 80,90 and $100 \%$ AT, showing more muscle damage than that found in the periodized training (de Araujo et al.). Furthermore, it was concluded that continuous aerobic training showed a time limit for positive adaptations in aerobic capacity which occurred after four weeks for the group at $90 \%$ AT, noting that a period of 12 weeks in rats may be excessive and does not cause physiological improvements.

These changes show that training with high volume is more prone to negative adjustments in rats (de Araujo et al.). Only the average value of the CS group showed a significant reduction in pre-and post-tLIM in the experiment, which can be justified by the long period of inactivity in the cage, and lack of training. Another important limitation may be the ergometer. Increasing lean muscle mass results in a decrease in buoyancy, which may contribute to a reduced swimming performance.

Thus, this study contributes to the literature by looking at the positive effects of HMB supplementation on rats. However, important limitations should be taken into consideration. One is the choice of ergometer used in this study, 
which may negatively influence aerobic performance. Another point to note is the use of animal groups subjected only to strength training and aerobic endurance. Further studies using different models of training and isolated groups according to the specificity may complement the present research.

It is concluded that supplementation with HMB was capable of increasing muscle mass, but was ineffective in promoting changes in aerobic capacity of rats after eight weeks of concurrent training.

ARAUJO, R. G.; CASTOLDI, R. C.; DOS SANTOS, C. C.; MACHADO, J. H. L.; OZAKI, G. A. T.; GARCIA, T. A.; TEIXERIRA, G. R.; FLHO, J. C. S. C. \& PAPOTI, M. Efecto de la suplementación con HMB sobre la composición corporal en ratas. Int. J. Morphol., 35(2):705-710, 2017.

RESUMEN: Se investigaron los efectos de la suplementación con HMB en el rendimiento físico y los parámetros antropométricos de ratas Wistar sometidas a ocho semanas de entrenamiento concurrente. La muestra consistió en 22 ratas Wistar machos, aproximadamente de 60 días de edad, los que fueron divididos en cuatro grupos: control (C), control suplementado (CS), ejercicio (E) y ejercicio suplementado (ES). El entrenamiento consistió en 30 minutos de natación correspondiente a $70 \%$ de la sobrecarga del umbral anaeróbico, un intervalo de un minuto y cuatro series de diez saltos en el agua con intervalo de un minuto entre series y una carga del $50 \%$ del peso del cuerpo. El tLIM y tTESTE se utilizaron para evaluar el rendimiento de los animales, y los índices antropométricos. El aumento de peso durante el tratamiento CS fue significativamente más alto que las de los grupos $\mathrm{C}$ y E. El peso absoluto de los músculos, los riñones y la grasa del epidídimo mostraron valores más altos en los grupos CS y ES en relación con los demás.

PALABRAS CLAVE: Entrenamiento concurrente; Rendimiento; Medidas Antropométricas; Ratas Wistar.

\section{REFERENCES}

Alvares, T. S. \& Meirelles, C. M. Efeitos da suplementação de b-hidroxi-bmetilbutirato sobre a força e a hipertrofia. Rev. Nutr., 21(1):49-61, 2008.

Bodine, S. C. mTOR signaling and the molecular adaptation to resistance exercise. Med. Sci. Sports Exerc., 38(11):1950-7, 2006.

Carvalho, A. D. G.; Barbosa, R. O.; Silva, R. C.; Carvalho, W. A. \& Percário, S. Biomarcadores do Estresse Oxidativo após Exercício Físico Exaustivo em Ratos Wistar. Trabalho de Conclusão de Curso. Manaus, Universidade do Amazônia, Centro de Ciências Biológicas da Saúde, 2009.

de Araujo, G. G.; Papoti, M.; Manchado, F. de B.; de Mello, M. A. \& Gobatto, C. A. Protocols for hyperlactatemia induction in the lactate minimum test adapted to swimming rats. Comp. Biochem. Physiol. A Mol. Integr. Physiol., 148(4):888-92, 2007.

de Lima, F. L.; Zamai, C. A. \& Bankoff, A. D. P. Correlação das variáveis: índice de massa corporal (IMC) e percentual de gordura corporal em uma população praticante regular de atividade física. Rev. Digit., 15(144), 2012. Available from: http://www.efdeportes.com/efd144/indice-de-massa-corporal-e-percentual-de-gordura-corporal.htm

De Mello Malheiro, O. C.; Giacomini, C. T.; Justulin, L. A. Jr.; Delella, F. K.; Dal-Pai-Silva, M. \& Felisbino, S. L. Calcaneal tendon regions exhibit different MMP-2 activation after vertical jumping and treadmill running. Anat. Rec. (Hoboken), 292(10):1656-62, 2009.

França, S. C. A.; Neto, T. L. B.; Agresta, M. C.; Lotufo, R. F. M. \& Kater, C. E. Resposta divergente da testosterona e do cortisol séricos em atletas masculinos após uma corrida de maratona. Arq. Bras. Endocrinol. Metab., 50(6):1082-7, 2006.
Gallagher, P. M.; Carrithers, J. A.; Godard, M. P.; Schulze, K. E. \& Trappe, S. W. Beta-hydroxy-beta-methylbutyrate ingestion, Part I: effects on strength and fat free mass. Med. Sci. Sports Exerc., 32(12):2109-15, 2000.

Guedes Junior, D. P. Treinamento Concorrente: Uma Abordagem Atual. São Paulo, Phorte Editora, 2003.

Knitter, A. E.; Panton, L.; Rathmacher, J. A.; Petersen, A. \& Sharp, R. Effects of beta-hydroxy-beta-methylbutyrate on muscle damage after a prolonged run. J. Appl. Physiol. (1985), 89(4):1340-4, 2000.

Leveritt, M.; Abernethy, P. J.; Barry, B. \& Logan, P. A. Concurrent strength and endurance training: the influence of dependent variable selection. $J$. Strength Cond. Res., 17(3):503-8, 2003.

McArdle, W. D.; Katch, F. I. \& Katch, V. L. Fisiologia do Exercício: Energia, Nutrição e Desempenho Humano. $5^{\circ}$ ed. Rio de Janeiro, Guanabara Koogan, 2003.

McCarthy, J. P.; Pozniak, M. A. \& Agre, J. C. Neuromuscular adaptations to concurrent strength and endurance training. Med. Sci. Sports Exerc., 34(3):511-9, 2002.

Nissen, S.; Sharp, R. L.; Panton, L.; Vukovich, M.; Trappe, S. \& Fuller, J. C Jr. beta-hydroxy-beta-methylbutyrate (HMB) supplementation in humans is safe and may decrease cardiovascular risk factors. J. Nutr., 130(8):1937$45,2000$.

Nunes, E. A.; Kuczera, D.; Brito, G. A.; Bonatto, S. J.; Yamazaki, R. K.; Tanhoffer, R. A.; Mund, R. C.; Kryczyk, M. \& Fernandes, L. C. Betahydroxy-beta-methylbutyrate supplementation reduces tumor growth and tumor cell proliferation ex vivo and prevents cachexia in Walker 256 tumor-bearing rats by modifying nuclear factor-kappaB expression. Nutr. Res., 28(7):487-93, 2008.

Paulo, A. C.; Souza, E. O.; Laurentino, G.; Ugrinowitsch, C. \& Tricoli, V. Efeito do treinamento concorrente no desenvolvimento da força motora e da resistência aeróbia. Rev. Mackenzie Educ. Fis. Esporte, 4(4):145-54, 2005.

Pereira, R. R.; Papoti, M.; Zagatto, A. M.; \& Gobatto, C. A. Validação de dois protocolos para determinação do limiar anaeróbio em natação. Motriz J. Phys., 8(2):63-8, 2002.

Souza, E. O. Efeitos do Treinamento Concorrente na Expressão Gênica e Protéica Associada a Hipertrofia Muscular. Dissertação de Mestrado. São Paulo, Escola de Educação Física e Esporte da Universidade Estadual Paulista, 2010.

Spagnol, A. R.; Malheiro, O. C. M.; Castoldi, R. C.; Moret, D. G.; Araújo, R. G.; Papoti, M.; Camargo, R. C. T. \& Camargo Filho, J. C. S. Análise da plasticidade muscular de ratos submetidos a um protocolo de treinamento físico concorrente. Rev. Bras. Cienc. Mov., 20(3):118-24, 2012.

Tegtbur, U.; Busse, M. W. \& Braumann, K. M. Estimation of an individual equilibrium between lactate production and catabolism during exercise. Med. Sci. Sports Exerc., 25(5):620-7, 1993.

Voltarelli, F. A.; Gobatto, C. A. \& de Mello, M. A. Determination of anaerobic threshold in rats using the lactate minimum test. Braz. J. Med. Biol. Res., 35(11):1389-94, 2002.

World Health Organization (WHO). The World Health Report 1998. Life in the 21st Century. A Vision for All. Geneva, World Health Organization, 1998.

\section{Corresponding Author:}

Prof. Ddo. Robson Chacon Castoldi

Universidade Estadual de Campinas - UNICAMP

Universidade do Oeste Paulista - UNOESTE

Universidade Estadual Paulista - UNESP

Laboratório de Análise da Plasticidade Muscular - LAPMus

Presidente Prudente - São Paulo - BRASIL

E-mail:castoldi_rc@yahoo.com.br

Received: 07-10-2016

Accepted: 13-03-2017 